Jurnal Ilmiah Farmasi 16(2) Agustus-Desember, Hal.196-203

ISSN: $1693-8666$

available at http://journal.uii.ac.id/index.php/JIF

\title{
Treatment pattern and direct medical costs of pediatric outpatients with actuate respiratory infection at $\mathrm{X}$ hospital in Jambi
}

\section{Pola pengobatan dan biaya medis langsung pasien ISPA anak rawat jalan di Rumah Sakit X Jambi}

\author{
Hendri Pranata*, Rasmaladewi, Mukhlis Sanuddin
}

Program Studi Farmasi, Sekolah Tinggi Ilmu Kesehatan Harapan Ibu, Jambi, Indonesia

*Corresponding author: hendri_pranata46@yahoo.co.id

\begin{abstract}
Introduction: Acute respiratory infection is common among the general public. Such disease and its associated symptoms encourage higher consumption of medicine. Varied medications for ARI patients incur different costs of each patient, which eventually lead to higher healthcare costs.

Objectives: To identify the treatment patterns and direct medical costs among ARI pediatric patients at X Hospital in Jambi.

Methods: This research was an observational study with retrospective data collection. The samples were collected in 2018.

Results: The results showed that the most-frequently administered antibiotic for ARI pediatric patients was cefixime (29.17\%), while the most-commonly used supportive therapy for ARI pediatric patients was the combination of antihistamines, antipyretics-analgesics, decongestant, and corticosteroid (16.67\%). The total direct medical cost to ARI pediatric patients was IDR 191,097.

Conclusion: The mean direct medical cost for ARI therapy was IDR 191,097. More administered therapy resulted in higher medical costs.

Keywords: ARI, child, antibiotics, direct medical costs

\section{Intisari}

Latar belakang: Infeksi saluran pernafasan akut merupakan penyakit yang umum terjadi pada setiap kalangan masyarakat. Infeksi saluran pernafasan akut dan juga gejala yang di timbulkannya mengakibatkan tinggi nya penggunaan obat-obatan. Bervariasinya obat yang di konsumsi oleh pasien ISPA menyebabkan pembebanan biaya yang beragam dari setiap pasien yang pada akhirnya akan mempengaruhi beban biaya kesehatan yang akan ditanggung.

Tujuan: Untuk mengetahui pola pengobatan dan biaya medis langsung pasien ISPA anak rawat jalan di Rumah Sakit X Jambi.

Metode: Penelitian ini merupakan penelitian observasional dengan pengumpulan data dilakukan secara retrospektif. Sampel diambil pada tahun 2018.

Hasil: Hasil penelitian didapatkan bahwa antibiotik yang paling banyak digunakan pada pasien anak penderita ISPA adalah sefiksim sebesar $29,17 \%$. Sedangkan terapi suportif yang paling banyak digunakan untuk pasien anak ISPA adalah kombinasi golongan antihistamin, antipiretik analgetik, dekongestan, kortikosteroid sebanyak $16,67 \%$. Biaya total rata-rata medis langsung pada pasien ISPA anak rawat jalan yaitu sebesar Rp. 191.097.

Kesimpulan: Biaya medis langsung yang harus dikeluarkan untuk terapi pada penyakit ISPA yaitu rata-rata sebesar Rp. 191.097. Semakin banyak terapi yang di berikan maka semakin tinggi pula biaya yang akan dikeluarkan.

Kata kunci: ISPA, anak, antibiotik, biaya medis langsung
\end{abstract}




\section{Latar Belakang}

Menurut World Health Organization (WHO), Infeksi Saluran Pernapasan Akut (ISPA) merupakan salah satu penyebab utama kesakitan dan kematian pada penyakit menular, diketahui sekitar empat juta orang meninggal diakibatkan oleh ISPA setiap tahun (WHO, 2019). Pada 10 penyakit terbanyak di Indonesia, ISPA selalu menduduki peringkat pertama. ISPA mendominasi kesakitan anak usia dibawah 5 tahun (balita) (Kemenkes, 2011). Di Indonesia karakteristik penduduk dengan ISPA yang tertinggi terjadi pada kelompok umur 14 tahun $(25,8 \%)$ (Musdalipah et al., 2018). Persentase untuk Kota Jambi sendiri mencapai 68,58\% sehingga dikhawatirkan dampak yang besar pada anak di Kota Jambi (Dinkes, 2016).

Dampak dari penyakit ISPA jika tidak diobati dan jika di sertai dengan malnutrisi, maka penyakit tersebut akan menjadi berat dan akan menyebabkan terjadinya bronkitis, pneumonia, otitis media, syok dan sebagainya (Marni, 2014). ISPA serta dampak yang timbul mengakibatkan tingginya penggunaan antibiotik dan obat seperti obat flu, obat batuk dan multivitamin. ISPA umumnya diberikan resep antibiotik, ekspektoran, analgetik dan antihistamin (Sholihah et al., 2017).

Bervariasinya terapi yang diberikan kepada pasien ISPA menimbulkan pembebanan biaya pengobatan yang beragam dari setiap pasien yang mempengaruhi total biaya pengobatan yang harus ditanggung (Almeman et al., 2014). Penelitian yang telah dilakukan menyatakan bahwa sebanyak 4.558 balita di Jakarta menderita ISPA pada tahun 2002 dengan total biaya yang harus dikeluarkan sebesar Rp.55.748.788,00, dan pada 2015 biaya medik langsung pasien ISPA anak di RS 'X' adalah Rp. 250.407 per pasien (Sholihah et al., 2017). Penelitian ini bertujuan untuk mengetahui biaya medis langsung serta pola pengobatan pasien ISPA anak rawat jalan di Rumah Sakit X Jambi.

\section{Metodologi penelitian}

\subsection{Deskripsi bahan dan teknik pengumpulan sampel}

Penelitian ini merupakan penelitian observasional dengan pengambilan data secara retrospektif berdasarkan data resep, slip bpjs dan kwitansi pembayaran pasien pediatrik yang telah menjalani pengobatan rawat jalan pada periode 2018 di Instalasi Rawat Jalan Anak Rumah Sakit X Jambi. Sampel pada penelitian ini adalah pasien anak penderita ISPA pada 
rawat jalan yang mendapatkan terapi pengobatan minimal 1 jenis pengobatan supportif dan atau 1 jenis antibiotik. Data disajikan dalam bentuk tabel.

\subsection{Penjelasan mengenai deskripsi jalannya penelitian}

Pengambilan sampel dilakukan dengan cara menelusuri resep, slip bpjs dan kwitansi pasien di poli anak Rumah Sakit X Jambi dengan data periode 2018. Data kemudian diolah menggunakan MS. Excel. Data dikelompokan berdasarkan karakteristik pasien, terapi yang diberikan, dan biaya medis langsungnya. Analisis data yaitu biaya medis langsung dihitung biaya rata-rata yang harus dikeluarkan per pasien untuk diagnosa ISPA.

\section{Hasil dan pembahasan}

Karakteristik pasien diperlihatkan pada tabel 1. Berdasarkan hasil penelitian yang telah dilakukan, persentase pasien ISPA anak rawat jalan berjenis kelamin laki-laki sebesar 54,17\% dan perempuan sebesar 45,83\%. Hal ini di karenakan kegiatan anak laki-laki lebih banyak dibandingkan perempuan sehingga anak laki-laki lebih banyak peluang terpaparnya agent penyakit (Sugiarti et al., 2015). Karakteristik pasien berdasarkan usia diperoleh hasil persentase pasien anak usia 0-5 tahun sebesar 70,83\% dan usia >5-12 tahun sebesar 29,17\%. Tingginya prevalensi tersebut dikarenakan ISPA pada usia tersebut biasanya merupakan kejadian infeksi pertama namun belum terbentuknya kekebalan tubuh yang optimal secara alami serta belum sempurnanya sistem imunitas (Fajarwati, 2015; Musdalipah et al., 2018).

Tabel 1. Karakteristik pasien berdasarkan jenis kelamin, usia, dan diagnosa penyakit

\begin{tabular}{llllllll}
\hline No & Karakteristik & Bronkitis & Otitis media & Rhinitis & Sinusitis & Total & \% \\
\hline $\mathbf{1}$ & Jenis kelamin & & & & & & \\
& Laki-laki & 19 & 6 & 5 & 9 & 39 & 54,17 \\
& Perempuan & 17 & 9 & 1 & 6 & 33 & 45,83 \\
& Total & 36 & 15 & 6 & 15 & 72 & 100 \\
\hline $\mathbf{2}$ & Usia & 30 & 7 & & & & \\
& $0-5$ tahun & 6 & 8 & 4 & 12 & 51 & 70,83 \\
& $>5-12$ tahun & 36 & 15 & 6 & 15 & 21 & 29,17 \\
& Total & & & & & 72 & 100 \\
\hline
\end{tabular}

Keterangan: Rentang usia berdasarkan Kementerian Kesehatan Republik Indonesia

Pola penggunaan antibiotik diperlihatkan pada tabel 2. Antibiotik yang paling banyak digunakan pada penelitian ini adalah sefiksim dengan penggunaan pada penyakit bronkitis dan sinusitis dengan total penggunaan sebesar 29,17\%, sedangkan pada otitis media lebih 
banyak menggunakan tetes telinga ofloksasin sebesar $6.94 \%$ dan pada rhinitis antibiotik yang digunakan adalah sefadroksil dengan total penggunaan pada semua penyakit sebesar 13,89\%. Sefiksim lebih banyak digunakan pada bronkitis dan sinusitis dikarenakan sefiksim dianggap pilihan terapi yang tepat untuk mengatasi infeksi mikroorganisme yang serius. Penelitian yang dilakukan sebelumnya menunjukan keberhasilan pengobatan sebesar $83,30 \%$ pada pasien sinusitis. Keberhasilan tersebut disebabkan karena sensitifitas sefiksim terhadap mikroorganisme penyebab sinusitis dan beberapa penyakit ISPA sehingga sefiksim lebih direkomendasikan sebagai terapi lini pertama untuk mengatasi infeksi sinusitis (Dreshaj et al., 2011). Penyakit bronkitis tidak hanya digunakan antibiotik sefiksim tetapi juga menggunakan antibiotik kombinasi amoksisilin dan asam klavulanat. Kombinasi ini dapat mengurangi resistensi terhadap amoksisilin (Alburyhi et al., 2013).

Tabel 2. Pola penggunaan antibiotik

\begin{tabular}{|c|c|c|c|c|c|c|c|c|}
\hline \multirow[t]{2}{*}{ No } & \multirow{2}{*}{ Golongan } & \multirow{2}{*}{ Nama obat } & \multicolumn{4}{|c|}{ Diagnosa } & \multicolumn{2}{|c|}{$\mathbf{N}=72$} \\
\hline & & & Bronkitis & Otitis Media & Rhinitis & Sinusitis & Jumlah & $\%$ \\
\hline \multirow[t]{2}{*}{1} & Sefalosporin & Sefadroksil & 4 & & 2 & 4 & 10 & 13,89 \\
\hline & & Sefiksim & 10 & & & 11 & 21 & 29,17 \\
\hline 2 & Kuinolon & Ofloksasin & & 5 & & & 5 & 6,94 \\
\hline \multirow[t]{2}{*}{3} & Penisilin & Amoksisilin & 5 & & 1 & & 6 & 8,33 \\
\hline & & Amoksiklav & 6 & & & & 6 & 8,33 \\
\hline \multirow[t]{6}{*}{4} & Makrolida & Azitromisin & 2 & & & & 2 & 2,78 \\
\hline & Kombinasi & $\begin{array}{c}\text { Amoksisilin + } \\
\text { Ofloksasin }\end{array}$ & & 2 & & & 2 & 2,78 \\
\hline & & $\begin{array}{c}\text { Amoksisilin + } \\
\text { Polimiksin + } \\
\text { Neomisin }\end{array}$ & & 2 & & & 2 & 2,78 \\
\hline & & $\begin{array}{c}\text { Amoksiklav + } \\
\text { Ofloksasin }\end{array}$ & & 2 & & & 2 & 2,78 \\
\hline & & $\begin{array}{c}\text { Polimiksin }+ \\
\text { Neomisin }\end{array}$ & & 1 & & & 1 & 1,39 \\
\hline & & $\begin{array}{c}\text { Sefadroksil + } \\
\text { Ofloksasin }\end{array}$ & & 3 & & & 3 & 4,16 \\
\hline \multirow[t]{2}{*}{5} & \multicolumn{2}{|c|}{ Tidak menerima antibiotik } & 9 & & 3 & & 12 & 16,67 \\
\hline & \multicolumn{2}{|c|}{ Total } & 36 & 15 & 6 & 15 & 72 & 100 \\
\hline
\end{tabular}

Pada rhinitis diberikan terapi antibiotik sefadroksil untuk mengatasi bakteri yang menyerang. Antibiotik golongan sepalosporin memiliki aktivitas yang poten terhadap mikroorganisme Gram positif dan Gram negatif. Otitis media lebih banyak digunakan obat 
tetes ofloksasin sebagai monoterapi. Ofloksasin tetes telinga diberikan pada penderita dengan sekret telinga. Antibiotik ini diketahui aman terhadap syaraf-syaraf telinga bila terjadi iritasi pada gendang telinga, yang berarti tidak bersifat ototoksik. Mekanisme kerja dari golongan kuinolon yaitu menghambat kerja DNA-gyrase sehingga sintesis DNA kuman terhambat (Sholihah et al., 2017).

Tabel 2 juga menunjukkan bahwa tidak semua pasien diberikan terapi antibiotik. Terapi antibiotik digunakan hanya jika adanya keterlibatan atau penyakit disebabkan oleh bakteri, sedangkan jika penyakit disebabkan oleh virus tidak perlu diberikan antibiotik, namun diberikan terapi suportif untuk mengurangi gejala penyakit dan antivirus jika dibutuhkan. Pengenalan ada tidaknya indikasi pemberian antibiotik menjadi masalah yang besar saat ini. Penggunaan antibiotik seharusnya didasarkan diagnosis yang jelas atau disebabkan oleh bakteri, namun pemeriksaan diagnostik terbatas membuat penegakan diagnosis pasti bisa tertunda hingga beberapa hari. Banyak peneliti menemukan bahwa sebagian besar alasan dokter memberikan antibiotik adalah karena adanya kekhawatiran dalam mengenali infeksi bakterial sehingga antibiotik diberikan kepada semua pasien dengan gejala demam (Farida et al., 2016).

Terapi suportif adalah terapi tambahan atau penunjang bukan antibiotik yang dapat menyembuhkan atau mengurangi gejala yang timbul. Penggunaan terapi ini di sesuaikan dengan keadaan yang dialami pasien (tabel 3.). Penggunaan lebih banyak digunakan obat dengan kombinasi antihistamin, antipiretik analgetik, dekongestan, kortikosteroid sebanyak 16,67\%. Penggunaan antihistamin umumnya digunakan jika adanya tanda alergi seperti gatal ataupun bersin, obat yang digunakan antihistamin golongan pertama yaitu CTM, golongan ini memberikan hasil yang baik dalam mengatasi gejala flu, namun tidak terbukti mencegah, ataupun mengobati serangan flu. Bronkodilator digunakan pada pasien bronkitis yang disertai dengan obstruksi peranafasan. Golongan ini mendilatasi bronkiolus dan bronkus sehingga aliran udara meningkat (Hapsari et al., 2010).

Tabel 3. Pola penggunaan terapi supportif

\begin{tabular}{ccc}
\hline Golongan & Jumlah & \% \\
\hline Antihistamin + Antipiretik-Analgetik + Mukolitik & 2 & 2,78 \\
Antihistamin + Antipiretik-Analgetik + Dekongestan + Kortikosteroid & 12 & 16,67 \\
Antihistamin + Antipiretik-Analgetik + Mukolitik & 2 & 2,78 \\
Antihistamin + Bronkodilator + Mukolitik & 10 & 13,89 \\
\hline
\end{tabular}




\begin{tabular}{ccc}
\hline Golongan & Jumlah & $\mathbf{\%}$ \\
\hline Antihistamin + Bronkodilator + Dekongestan + Mukolitik & 1 & 1,39 \\
Antihistamin + Dekongestan + Kortikosteroid + Vitamin & 5 & 6,94 \\
Antihistamin + Dekongestan + Kortikosteroid & 3 & 4,16 \\
Antihistamin + Kortikosteroid & 1 & 1,39 \\
Antihistamin-Kortikosteroid + Antipiretik-Analgetik & 3 & 4,16 \\
Antihistamin + Kortikosteroid + Mukolitik + Vitamin & 1 & 1,39 \\
Antipiretik-Analgetik + Bronkodilator + Mukolitik & 1 & 1,39 \\
Antipiretik-Analgetik + Dekongestan & 3 & 4,16 \\
Antipiretik-Analgetik + Mukolitik & 3 & 4,16 \\
Antipiretik-Analgetik + Mukolitik + Vitamin & 1 & 1,39 \\
Antipiretik-Analgetik + Kortikosteroid + Mukolitik & 2 & 2,78 \\
Antipiretik-Analgetik + Vitamin & 1 & 1,39 \\
Bronkodilator & 1 & 1,39 \\
Bronkodilator + Mukolitik & 2 & 2,78 \\
Bronkodilator + Dekongestan + Kortikosteroid + Mukolitik + Vitamin & 1 & 1,39 \\
Bronkodilator + Kortikosteroid +Mukolitik + Vitamin & 5 & 6,94 \\
Dekongestan + Ekspektoran + Kortikosteroid & 1 & 1,39 \\
Kortikosteroid + Mukolitik & 8 & 11,12 \\
Kortikosteroid + Mukolitik + Vitamin & 2 & 2,78 \\
Mukolitik + Vitamin & 1 & 1,39 \\
\hline Total & 72 & 100 \\
\hline
\end{tabular}

Biaya medis langsung merupakan biaya yang dikeluarkan oleh pasien yang berhubungan langsung dengan kesehatan pasien seperti biaya pendaftaran, jasa dokter dan obat-obatan (tabel 4). Hasil penelitian menunjukan bahwa biaya langsung yang harus dikeluarkan oleh pasien ISPA rawat jalan yaitu sebesar Rp. 191.097. Biaya tertinggi yang harus dibayar oleh pasien adalah biaya pendaftaran dan jasa dokter (digabung).

Tabel 4. Biaya medis langsung

\begin{tabular}{ccc}
\hline Medis langsung & \multicolumn{2}{c}{$\mathbf{N = 7 2}$} \\
\cline { 2 - 3 } & Biaya total & Biaya per pasien \\
\hline Obat & Rp. 2.581 .500 & Rp. 35.854 \\
Antibiotik & Rp. 2.537 .500 & Rp. 35.243 \\
Suportif & Rp. 8.640 .000 & Rp. 120.000 \\
\hline Jasa Dokter dan Pendaftaran & Rp. 13.759 .000 & Rp. 191.097 \\
\hline Total &
\end{tabular}

Biaya jasa dokter adalah biaya yang dikeluarkan sebagai imbalan kepada dokter karena telah melakukan pemeriksaan dan konsultasi terhadap pasien ataupun keluarga pasien. Biaya pendaftaran dan jasa dokter yang harus dikeluarkan yaitu sebesar Rp. 120.000. 
Biaya penggunaan obat yang harus dikeluarkan oleh pasien ISPA anak rawat jalan ada 2 jenis yaitu terapi suportif dan antibiotik. Biaya antibiotik yang harus dikeluarkan tiap pasien yaitu sebesar Rp. 35.854 sedangkan biaya terapi suportif tiap pasien yaitu sebesar Rp. 35.243.

Dari data tersebut menunjukan bahwa terapi antibiotik lebih tinggi biayanya dibandingkan dengan biaya suportif. Hal ini disebabkan karena adanya penggunaan antibiotik kombinasi dan antibiotik dengan bentuk sediaan sirup (Musdalipah et al., 2018). Antibiotik sirup umumnya lebih mahal dibandingkan dengan yang tablet/kapsul, dan pasien yang paling banyak adalah usia 0-5 tahun sehingga lebih banyak digunakan antibiotik sirup. Hal ini mempengaruhi biaya yang dikeluarkan oleh pasien.

\section{Kesimpulan}

Hasil penelitian didapatkan bahwa antibiotik yang paling banyak digunakan pada penelitian ini yaitu sefiksim sebanyak 29,17\%. Terapi suportif yang paling banyak digunakan adalah kombinasi golongan antihistamin, antipiretik-analgetik, dekongestan, kortikosteroid sebesar $16,67 \%$. Biaya medis langsung yang harus dikeluarkan pada penelitian ini didapatkan dengan rata-rata yaitu sebesar Rp.191.097 per pasien.

\section{Ucapan terimakasih}

Terima kasih kepada Rumah Sakit 'X' dan STIKES Harapan Ibu Jambi yang telah mengizinkan dilaksanakannya penelitian ini serta membantu dalam kelancaran pelaksanaan penelitian ini.

\section{Daftar pustaka}

Alburyhi, M. M., Siaf, A. A., \& Noman, M. A. (2013). Stability study of six brands of amoxicillin trihydrate and clavulanic acid oral suspension present in Yemen markets. Journal of Chemical and Pharmaceutical Research, 5, 293-296.

Almeman, A., Ibrahim, M., \& Rasool, S. (2014). Cost analysis of medications used in upper respiratory tract infections and prescribing patterns in University Sans Malaysia, Penang, Malaysia. Tropical Journal of Pharmaceutical Research, 13, 621. doi:10.4314/tjpr.v13i4.21

Dinkes. (2016). Profil Kesehatan Provinsi Jambi. Jambi: Dinas Kesehatan Provinsi Jambi

Dreshaj, S., Doda-Ejupi, T., Tolaj, I., Mustafa, A., Kabashi, S., Shala, N., Geca, N., Aliu, A., \& Daka, A. (2011). Clinical role of Cefixime in community-acquired infections. Prilozi / Makedonska akademija na naukite i umetnostite, Oddelenie za biološki i medicinski nauki = Contributions / Macedonian Academy of Sciences and Arts, Section of Biological and Medical Sciences, 32, 143-155.

Fajarwati, A. H. (2015). Evaluasi penggunaan antibiotika pada penyakit Infeksi Saluran Pernafasan Akut kelompok pediatri di Instalasi Rawat Inap Rumah Sakit Panti Rapih Yogyakarta. Universitas Sanata Dharma, Yogyakarta. 
Farida, H., Herawati, H., Hapsari, M. M., Notoatmodjo, H., \& Hardian, H. (2016). Penggunaan Antibiotik Secara Bijak Untuk Mengurangi Resistensi Antibiotik, Studi Intervensi di Bagian Kesehatan Anak RS Dr. Kariadi. Sari Pediatri, 10, 34. doi:10.14238/sp10.1.2008.34-41

Hapsari, R. Y. D., Sunyoto, \& Rahmawati, F. (2010). Gambaran Pengobatan Pada Penderita Ispa (Infeksi Saluran Pernafasan Akut) Di Puskesmas Trucuk 1 Klaten Tahun 2010. CERATA Journal of Pharmacy Science, 11.

Kemenkes. (2011). Pedoman Pengendalian Infeksi Saluran Napas Akut. Kementerian Kesehatan Republik Indonesia

Marni. (2014). Asuhan Keperawatan pada Anak dengan Gangguan Pernapasan. Yogyakarta: Gosyen Publishing.

Musdalipah, M., Setiawan, M. A., \& Santi, E. (2018). Analisis efektivitas biaya antibiotik sefotaxime dan gentamisin penderita pneumonia pada balita di RSUD Kabupaten Bombana Provinsi Sulawesi Tenggara.

Sholihah, N., Susanti, R., \& Untari, E. (2017). Gambaran pengobatan dan biaya medis langsung pasien ISPA anak di RS ' $\mathrm{X}$ ' tahun 2015. JURNAL MANAJEMEN DAN PELAYANAN FARMASI Journal of Management and Pharmacy Practice), 7, 40. doi:10.22146/jmpf.368

Sugiarti, T., Sidemen, A., \& Wiratmo, W. (2015). Studi Penggunaan Antibiotik pada Pasien Penyakit ISPA Usia Bawah Lima Tahun di Instalasi Rawat Jalan Puskesmas Sumbersari Periode 1 Januari-31 Maret 2014 (Study of Antibiotics Use on ARI Patients in Under Five Years Outpatient Clinic, Sumbersari Health. Pustaka Kesehatan(2), 262-266\%V 263. Retrieved from https://jurnal.unej.ac.id/index.php/IPK/article/view/2583

WHO. (2019). World health statistics 2019: monitoring health for the SDGs, sustainable development goals(pp. 120). Retrieved from https://apps.who.int/iris/handle/10665/324835 